\title{
Türkiye’de İngilizce Öğrenmek: Zorluklar ve Fırsatlar
}

İsmail YAMAN ${ }^{1}$

\author{
$\ddot{O} \mathbf{z}$
}

İngilizce öğrenmek tüm dünyada olduğu gibi Türkiye'de de yllardır büyük önem atfedilen bir uğraştır. İngilizce eğitiminin başlama yaşının yllar içinde giderek düşürülmesi bunun en net göstergelerinden biridir. Mevcut çalışma bugün neredeyse tüm dünyada ortak iletişim dili olarak kullanılan İngilizcenin Türkiye'de yabancı dil olarak öğretimi ve öğrenimi noktasında yaşanan zorlukları ve sonrasında bu çerçevede var olan kolaylıkları ortaya koymayı amaçlamaktadır. $\mathrm{Bu}$ doğrultuda, çalışmanın giriş kısmında Türkiye'de genel olarak yabancı dil öğretiminin ve özelde İngilizce öğretiminin tarihsel gelişimi ana hatlarıyla ele alınmıştır. Ayrıca, Türkiye'de İngilizce öğretiminin ürünlerini ortaya koyan verilerle mevcut durum gerçekçi bir şekilde ortaya konmuştur. Sonrasında ise Türkiye'de İngilizce öğrenme sürecini güçleştiren Türkiye'de İngilizcenin ikinci dil değil yabancı bir dil olması, öğretmen nitelikleri bağlamında bulunan eksiklikler, dil öğrenmenin özellikle yabancı dil ortamlarında zaman ve sabır gerektiren bir süreç olması, İngilizceye ve dil öğrenme sürecine dair mevcut önyargılar, atılan önemli adımlara rağmen yerli kitapların istenilen seviyeye gelememesi ve ölçme-değerlendirme araçlarının öğrenmeyi destekleyecek ölçüde etkin kullanılamaması gibi temel etkenler ayrıntılı bir şekilde tartışılmışıı. Zorluklar ele alındıktan sonra, bugün Türkiye'de İngilizce öğrenmeyi kolaylaştıran iyi hazırlanmış güncel İngilizce dersi öğretim programları, dil eğitimini destekleyici teknolojik gelişmeler, erişilebilecek sınırsız kaynak çeşitliliği, etrafta ve günlük yaşantımızda yararlanılabilecek İngilizce unsurlar ve artan uluslararası projeler kapsamında değişim programları gibi etkenler de ayrıntılı olarak ele alınmıştır. Çizilen çerçevede Türkiye bağlamında İngilizce öğretimine yapıcı katkı sağlayacak bazı öneriler de sunulmuştur.

Anahtar kelimeler: İngilizce, dil eğitimi, zorluklar, firsatlar.

\section{Learning English in Turkey: Challenges and Opportunities}

\begin{abstract}
As in all the world, learning English is a struggle that has been attributed great importance for many years in Turkey. The gradual reduction of the age of the onset of English education over the years is one of the clearest indicators of this. The present study aims to discuss the challenges experienced in Turkey in the learning and teaching process of English that is today used as a lingua franca almost all over the world and then the available opportunities that render this process easier. In this respect, the introduction of this study focuses on the historical development of foreign language teaching in general and teaching English in particular in Turkey. Also, the current situation is presented realistically with data demonstrating the products of English language teaching in Turkey. Then, challenging factors like Turkey's being an English as a foreign language (EFL) country, deficiencies in teacher qualifications, that language learning is a demanding process that requires time and patience especially in EFL settings, the existing prejudices about the English language and the language learning process, that domestic English course books have not been able to attain a desired level in spite of some important steps taken, and that the assessment tools cannot be used effectively
\end{abstract}

Dr. Öğr. Üyesi, Ondokuz Mayıs Üniversitesi, Eğitim Fakültesi, Yabancı Diller Eğitimi Bölümü, ismail.yaman@omu.edu.tr [Makale kayıt tarihi: 27.3.2018-kabul tarihi: 14.4.2017] 


\begin{abstract}
to support learning have been discussed in detail. Following challenges, facilitating factors like the current well-prepared English curricula that enhance learning English in Turkey, technological developments, unlimited accessible resources, English components that are readily available all around us in our daily lives, and increasing international projects that offer exchange programs have been extensively discussed. Some constructive suggestions have also been offered in the context of English language learning and teaching in Turkey.
\end{abstract}

Key words: English, language education, challenges, opportunities.

\title{
Giriş
}

Yabancı dil öğrenmek ülkemizde pek çok kişinin çokça zaman ve para harcadığı bir süreç olarak çıkıyor karşımıza. Özellikle İngilizcenin dünya çapında ortak iletişim dili (lingua franca) hâline gelmesiyle yediden yetmişe herkes İngilizce öğrenmek adına bir çaba gösteriyor. İngilizceye hâkim olmak aslında diğer pek çok toplumda olduğu gibi bizim toplumumuzda da bir güç ve statü göstergesi olarak değerlendirilebiliyor (Doğançay-Aktuna, 1998). İnsanlar kendileri öğrenemiyorsa bile yabancı dil konuşabilen insanlara gıpta ile bakıyor ve çocuklarını bu bağlamda teşvik ediyor. İngilizce kadar olmasa da son yıllarda ülkemizde yabancı dil olarak etkisi artan Arapça, Rusça, İspanyolca ve Çince gibi dilleri öğrenmek için de insanlar büyük çaba ve zaman sarf ediyor. Bir de bu süreç başarısızlıkla sonuçlanırsa dil öğrenmeye karşı çok ciddi önyargılar oluşabilmektedir. Örneğin, İngilizcenin çok zor olduğunu iddia edenler, Türkiye’de yabancı dil öğretilemediğini söyleyenler, öğretmenlerin hep gramer ağırlıklı dersler yapıp onlara yeterince beceri kazandıramadıklarından yakınanlar veya artık dil öğrenmek için yaşlarının geçtiğini söyleyen insan sayısı oldukça fazladır. Bu tür yakınmaların haklı ya da haksız olduğunu tek bir pencereden bakıp söyleyemeyiz. Dil öğrenme sürecini başarılı ya da başarısız kılan pek çok etken olduğu için olaya büyük resmi görmeye çalışarak yaklaşmakta fayda vardır.

Türkiye'de yabancı dil öğretimi geleneği Osmanlı İmparatorluğu zamanında başlamıştır. O dönemde özellikle medreselerde Arapça eğitimi ön plana çımış ve sonrasında farklı mekteplerde Fransızca, Farsça, İngilizce, Almanca, İtalyanca, Rumca ve Bulgarca gibi diller de öğretilmeye başlamıştır; ancak Osmanlı döneminde de yabancı dil öğretiminde tam bir başarı yakalanamamıştır (Ergin, 1977). Osmanlı'nın son döneminde Lisan Mektepleri bünyesinde Fransızca başta olmak üzere yabancı dil eğitimi verilmiş; Galatasaray Lisesi bünyesinde Fransızca, Robert Koleji bünyesinde ise İngilizce eğitim verilmeye başlanmıştı (Çakır, 2017).

Zaman içinde Fransızca etkisini yitirdikçe İngilizcenin Türkiye'de yabancı dil olarak hâkimiyeti arttı. Özellikle de Türkiye'nin NATO üyeliği ve Avrupa Birliği üyeliği gündemi İngilizcenin etkisini daha da artırmıştır (Demirpolat, 2005). Yüksek Öğretim Kurulu (YÖK) öncesi dönemde kurulmuş olan Eğitim Enstitüleri dil eğitimi işini Milli Eğitim Bakanlığı (MEB) çatısı altında yürütürken, YÖK sonrası dönemde bu enstitüler Eğitim Fakültelerine dönüştürülerek yabancı dil eğitiminin ağırlı̆̆ı, özellikle İngilizce öğretmeni yetiştirme boyutuyla, üniversitelere aktarılmış oldu (Çakır, 2017).

Yakın zamanlara gelindiğinde ise, 1997 Sekiz Ylllık Eğitim Reformu'nu genel eğitim sistemi bağlamında bir eşik olarak değerlendirilebilir; ancak o dönemde İngilizcenin öğretim programının geleneksel yaklaşımdan uzaklaşmadığı görülmektedir. (Haznedar, 2004; Kırkgöz, 2007). Buna rağmen, daha önce ortaöğretim düzeyinde başlayan İngilizce derslerinin 4. sınıftan itibaren başlatılması ve 'erken yaş' ilkesinin gözetilmesi önemli bir kazanım olarak değerlendirilebilir. Devam eden süreçte ise, yeni bir öğretim programı 2006 yılında uygulamaya konulmuş ve bu yeni müfredat İngilizcenin 4. sınıftan 
itibaren bütüncül ve iletişimsel bir yaklaşımla öğretilmesi hususunda önemli bir zemin teşkil etmiştir (Haznedar, 2010).

2012-2013 Eğitim-Öğretim Yılı itibariyle yürürlüğe giren 4+4+4 eğitim sistemiyle ilkokula başlama yaşı 5'e (gönüllülük esasına göre) indirildi; İngilizce eğitimi ise 2. sinıftan itibaren verilmeye başladı (Bayyurt, 2012). Dolayısıyla, okula 5 yaşında başlayan bir çocuk 6 yaşında İngilizceyle tanışmaya başladı. Bu reform çerçevesinde, 2013 yllında uygulamaya konan yeni öğretim programıyla birlikte İngilizce eğitimi artık 2. sinıftan itibaren öğretilmek üzere yeniden planlandı. Öğretim sürecinde Diller İçin Avrupa Ortak Başvuru Metni (Common European Framework of Reference for Languages-CEFR) ilkeleri çerçevesinde iletişimsel ve eylem odaklı bir yaklaşım benimsendi. 2018 itibariyle ise bir önceki müfredat, İngilizce öğretmenleri, üniversiteler, sivil toplum kuruluşları gibi geniş bir çevrenin görüş ve katkıları da alınarak kısmen güncellendi ve aynı felsefe ve ilkeler doğrultusunda değerler eğitimi boyutunu da içine alacak şekilde yeniden bir çerçeve çizildi.

Gelmiş olduğumuz noktada, ülkemizde İngilizce öğretimi devlet okullarında 2. sınıftan itibaren, özel okulların hemen hepsinde ise 1. sınıftan itibaren başlatılmaktadır. Hatta okul öncesi eğitim kurumlarının çoğunda da öğrenci yavaş yavaş İngilizceyle tanıştırılmaktadır. Erken yaşta dil eğitimi aslında ülkemizde geç kalmış bir uygulamadır. Avrupa Birliği üyesi ülkelerin hepsinde yabancı dil eğitimi 1. sınıftan itibaren başlamaktadır (Bayyurt, 2012). Orta Doğu ve Kuzey Afrika Bölgesi ülkelerini değerlendirdiğimizde de durumun benzer olduğunu görüyoruz. Türkiye ve İngilizce eğitimini 4. sinıftan itibaren başlatan Suudi Arabistan hariç diğer bütün bölge ülkeleri yabancı dil eğitimini devlet okullarında 1. sınıftan itibaren başlatmaktadır (Kirkpatrick, 2017). Dolayısıyla, Türkiye’nin İngilizce eğitimini 2. sınıftan itibaren başlatması dünya gerçekleri dikkate alındığında abartılı değil, geç kalınmış bir adım olarak bile değerlendirilebilir.

Ülkemizde yabancı dil eğitimi şu anda hem 4+4+4 sistemi kapsamında ilkokul, ortaokul ve liselerde hem de yükseköğretim düzeyinde üniversitelerde verilmektedir. Yabancı dil olarak ağırlıklı İngilizcenin öğretildiği ülkemizde, özellikle lise ve üniversitelerde Almanca, Fransızca, Rusça, Arapça, Çince, İtalyanca, İspanyolca gibi diller de isteğe bağlı olarak öğretilmektedir. Hatta yükseköğretim düzeyinde, ODTÜ ve Boğaziçi Üniversitesi gibi üniversiteler yllardır eğitim dili tamamen İngilizce olarak faaliyetlerini sürdürmektedir. Eğitim dili Türkçe olan üniversitelerde de bazı bölümler yüzde yüz İngilizce (örneğin; İngilizce Tıp) bazı bölümler de ise yüzde otuz İngilizce eğitim vermektedir. Ĕ̆itimi tamamen Türkçe olan bölümlerde ise genellikle 1. sınıfta haftada en az 2 saat olmak üzere genel İngilizce eğitimi verilir. Meslek yüksekokullarındakiler dâhil üniversitelerdeki bölümlerin çoğunda ilerleyen dönemlerde Mesleki İngilizce dersi de verilmektedir.

Yukarıda bahsedilen kronolojik gelişmeler ışı̆̆ında Türkiye'de genelde yabancı dil eğitiminin özelde ise İngilizce öğretiminin nereden nereye geldiğine dair bir çerçeve ortaya koymaya çalıştık. Görünen o ki öğrenciler eğitim hayatlarının neredeyse tamamında İngilizceye temas etmektedir. Mevcut yetişkinlerin önemli bir kısmı da kendi imkânlarıyla özel dersler, kursalar, bireysel çalışmalar gibi yollarla İngilizce öğrenmeye çabalamaktadır.

Türkiye'de İngilizce öğretim süreçlerinin ürün ve yansımalarına baktığımızda, British Council ve TEPAV (2014) tarafından ortak yürütülen “Türkiye'deki Devlet Okullarında İngilizce Dilinin Öğretimine İlişkin Ulusal İhtiyaç Analizi” adlı çalışma kapsamında İngilizce öğretmenlerinin potansiyellerini tam olarak sınıfa yansıtamamaları, ders kitabına fazla bağımlı kalma, öğretmen odaklı bir eğitim verilmesi ve öğrencilerin bireysel özelliklerinin yeterince dikkate alınmaması gibi ana sorunlar tespit edilmiş ve bu 
bağlamda kuram ve uygulama arasındaki uçurumu gidermeye yönelik çeşitli çözüm önerileri getirilmiştir.

British Council ve TEPAV (2015) tarafindan ortak yürütülen "Türkiye'de Yükseköğretim Kurumlarında İngilizce - Bir Durum Analizi” adlı bir diğer çalışma kapsamında ise üniversitelerdeki İngilizce eğitimine dair bazı sorunlar tespit edilmiş ve çözüm olarak hazırlık sınıflarının seçmeli olması veya yalnızca eğitim dili İngilizce olan üniversitelerde uygulanması ve müfredatın genel amaçlı İngilizceden genel akademik amaçlı İngilizceye dönüştürülmesi gibi öneriler getirilmiştir.

2017 İngilizce Yeterlik Endeksi (English Proficiency Index) (https://www.ef.com.tr/epi/regions/europe/turkey/) verilerine göre Türkiye Hollanda'nın birincilik koltuğuna oturduğu araştırma kapsamında 80 ülke arasında 47.79 puanla 62. olarak 'çok düşük seviye' kategorisinde kendine yer bulmuştur. 27 Avrupa ülkesi arasında ise 26. sıradayız. Aynı araştırmanın önceki yıllara ait verilerine baktığımızda ise 2011 yılında 44 ülke arasında 43.; 2012'de 54 ülke arasında 32.; 2013'te 60 ülke arasında 41.; 2014'te 63 ülke arasında 47.; 2015'te 70 ülke arasında 50.; 2016 yllında ise 72 ülke arasında 51. sırayı aldığımız görülmektedir. Düzey olarak sadece 2012 ve 2013 yıllarında 'düşük seviye' kategorisinde yer aldığımız bu endekste bu yıl da dâhil olmak üzere çoğunlukla 'çok düşük seviye’ kategorisinde yer almaktayı. Türkiye'deki bölgeler özelinde en yüksek İngilizce seviyesi İç Anadolu Bölgesi’nde çıkarken en düşük düzey Güney Doğu Anadolu Bölgesi’nde çıkmıştır. Cinsiyet açısından ise veriler Türkiye'deki kadınların erkeklerden daha iyi İngilizce bildiğini göstermektedir.

Bu bağlamda, aşağıda Türkiye'de İngilizce öğrenmeyi güç kılan unsurları ve sonrasında tam tersine bu süreçte kolaylıklar sağlayabilen boyutları ele alacağız.

\section{Zorluklar}

\section{İngilizce Türkiye’de İkinci Dil Değil Yabancı Bir Dildir}

İngilizcenin ülkemizde öğrenilmesini güç kılan başlıca etken bu dilin Türkiye'de yabancı dil olmasıdır. Toplumdilbilimci Kachru (1985) İngilizcenin kullanıldığı ülkeleri üç ana çember içinde sınıflamıştır: iç çember (inner circle), dış çember (outer circle) ve genişleyen çember (expanding circle). İç çemberde yer alan Amerika, İngiltere, Avustralya gibi ülkelerde İngilizce anadil olarak konuşulmaktadır. Dış çemberde yer alan Hindistan, Güney Afrika Cumhuriyeti, Pakistan ve Kenya gibi ülkelerde İngilizce ikinci dil olarak konuşulmaktadır. Yani bu ülkelerin çoğunda İngilizce hem resmi dil (official language) hem de yaygın eğitim dili olarak da karşımıza çıkmaktadır. Dolayısıyla toplum İngilizceye çok rahat bir şekilde erişebilmektedir. Bu çemberdeki ülkelerin ortak özelliği çoğunun eski Britanya sömürgesi olmasıdır. Bu ülkeler üstünde sömürge düzeni kuran Britanya bahsedilen toplumların dili ve kültürü üstünde de olumsuz anlamda etkili olmuş ve yetişen nesillerde kayıplı iki dilliliğe (subtractive bilingualism) neden olmuştur. Genişleyen çemberde yer alan Türkiye, Rusya, Çin ve Japonya gibi ülkelerde ise İngilizce yabancı dil olarak öğrenilir ve kullanılır. Bu ülkelerin ortak özelliği ise İngilizcenin buralarda zor öğrenilmesidir.

Kachru'nun (1985) ortaya koyduğu üç çembere destek olarak Krashen'ın (1982) Edinim-Öğrenme Hipotezi'nden bahsetmek yerinde olur. Bu hipoteze göre anadil ve ikinci dil ortamlarında edinim gerçekleşirken yabancı dil ortamlarında edinimin gerçekleşmesi neredeyse imkânsızdır. Onun yerine gelişen süreç öğrenme sürecidir. Bu iki boyut arasındaki farkı aslında hedef dile maruz kalma derecesi 
belirlemektedir. Dile uzun süreli olarak bilinçaltına etki edecek derecede temas etmek edinim sürecini getirmektedir. Bu temas süreci bir de erken yaşta gerçekleşirse alınan verim çok daha iyi olmaktadır.

Öğrenme süreci ise dile hâkimiyet noktasında edinim kadar güzel sonuçlar vermemektedir. Türkiye genişleyen çembere ait ve İngilizcenin yabancı bir dil olarak öğrenildiği bir ülke olduğu için İngilizce burada edinilmiyor, öğreniliyor. Bu da teknik açıdan ciddi bir dezavantaj doğuruyor. İngilizceyi öğrenenler bu dile genellikle sınıf ortamlarında temas etmektedir. Basit bir hesap yaparsak, bir haftada 168 saat vardır ve haftada 24 saat İngilizce dersi alan birisinin bile bu dile temas ettiği oran $1 / 7$ olarak karşımıza çıkmaktadır. Haftada 2 saat İngilizce öğrenen birisi için bu oran 1/84. Onun haricinde kendi özel çabaları olmazsa, sokakta, evde, otobüste veya herhangi bir yerde İngilizceye temas etmezler. Ĕ̆gr bir dil günlük yaşamda karşılaşılmayan ve hayatta kalma (survival) veya ihtiyaçları karşılama noktasında elzem bir ihtiyaç olarak hissedilen bir araç değilse o dilde beceri geliştirme süreci haliyle keyfi ve yavaş olacaktır. Dolayısıyla İngilizceyi Türkiye'de öğrenen birisi Hindistan'da veya Norveç’te öğrenen birisinden her zaman daha dezavantajlı olacaktır. Bu durum bugün nasılsa, yarın da öyle olacaktır. Bu noktada hayıflanacak da bir şey yok aslında; iyi ki bir sömürge ülkesi değiliz ve iyi ki İngilizce ülkemizde ikinci değil yabancı bir dil. Elbette ki, bu bakış açımız İngilizcenin önemini ve öğrenilmesi elzem olan bir dil olduğu gerçeğini yadsımıyor. Aksine, gerçeği tespit edip ona göre telafi adımlarının atılması gerektiğini öngörüyor. Bu bağlamda, karşılaştırma yaparken de genişleyen çemberde bulunan ülkelerdeki dil eğitimi süreçleriyle kıyaslamalar yapmak yaşadığımız zorlukları aşma noktasında daha sağlıklı çözümlemeler yapmamıza yardımcı olacaktır.

\section{Öğretmen Nitelikleri}

Son yıllarda, özellikle Yapılandırmacı Yaklaşım çerçevesinde, öğrenen özerkliğinden (learner autonomy) bahsediyoruz. Özerklik boyutu yukarıda bahsedilen İngilizceye temas etme süresinin okuldaki ders saatiyle sınırlı kalmasını ortadan kaldıracak çok önemli bir boyuttur. Bunu da öğrenen kişi öğrenme sürecinin sorumluluğunu kendisi üstlenerek başarır. Ancak terimin isminden de anlaşılacağı üzere öğrenen kişi okul dışı öğrenme süreçlerini bağımsız değil özerk bir şekilde yürütür. Bu da İngilizce öğretmenini, özellikle de Türkiye gibi İngilizcenin yabancı dil olarak öğretildiği ortamlarda, dil öğretme veya öğrenme sürecinde vazgeçilmez bir aktör kılar. Tam da bu noktada, geleneksel eğitim jargonuyla İngilizceyi öğrencilere öğretecek, yapılandırmacı jargonla da onlara İngilizce öğrenme sürecinde rehberlik edecek öğretmenlerin niteliği konusu gündeme geliyor.

Türkiye'de İngilizce öğretmenlerinin niteliklerinden bahsetmek için birkaç farklı boyuta değinmek gerekiyor. Bunlardan ilki 'İngilizceyi anadil konuşuru (native speaker) olmayan birisi etkili olarak öğretebilir mi’ sorusudur. Bu konuda önemli çalışmaları bulunan Medgyes (1994) anadil konuşuru olan öğretmenlerin (NESTs) dile hâkimiyet, özgüven gibi konularda avantajlı olduğunu ifade ederken anadil konuşuru olmayan öğretmenlerin (Non-NESTs) de ülkedeki eğitim sistemine hâkimiyet, İngilizce öğrenme sürecinden geçmiş olmaları ve bu bağlamda başarılı bir rol model teşkil etmeleri ve öğrencilerin karşılaşabilecekleri sorunları tahmin edebilmeleri gibi çeşitli avantajları bulunduğunu ifade etmektedir. Ülkemizdeki durumu değerlendirdiğimizde ilkokul, ortaokul ve lise düzeyi devlet okullarında anadil konuşuru İngilizce öğretmen sayısı bir elin parmaklarını geçmez. Ancak özel okullar ve özel dil kursları biraz da pazarlama motivasyonuyla anadil konuşuru istihdam etme noktasında büyük çaba harcamaktadır. Üniversite düzeyinde ise İngilizce ile alâkalı bölümlerin çoğunda anadil konuşurları bulunmaktadır. Bunlardan bazısı tam zamanlı çalışan ve uzun süredir Türkiye'de bulunan öğretim elemanları iken bazıları da Amerikan Eğitim Ataşeliği kanalıyla ikili anlaşmalarla geçici statüde üniversitelerde görevlendirilen genç öğretim elemanlarından oluşmaktadır. 
Özetle, ülke genelinde İngilizce eğitimi işinin ağırlıklı yükünü üstlenen kesimin çok büyük çoğunluğu bizim eğitim sistemimizde yetişmiş yerli öğretmenlerden oluşmaktadır. Önceden İngilizce öğretmeni sayısı çok az olduğundan derslere farklı branşlardan öğretmenler girebiliyordu. Hatta ODTÜ ve Boğaziçi Üniversitesi gibi eğitim dili tamamen İngilizce olan üniversitelerin herhangi bir bölümünden mezun olanlar İngilizce ağırlıklı eğitim veren Anadolu Liselerinde İngilizce öğretmeni olarak görev alabiliyordu. Ayrıca, uzun bir süre üniversitelerin Almanca Öğretmenliği ve Fransızca Öğretmenliği gibi programlarda okuyan öğrenciler lisans eğitimleri esnasında İngilizce Öğretmenliği programlarından seçmeli 40 kredilik ders alarak edindikleri sertifikayla mezun olduklarında ihtiyaç olması durumunda İngilizce Öğretmeni olarak atanabildiler. Bugün Millî Eğitim Bakanlığı Okul Öncesi Eğitim Ve İlköğretim Kurumları Yönetmeliği’nin ilgili maddesi şöyle diyor: "İlkokullarda bütün derslerin sınıf öğretmenlerince okutulması esastır. Ancak Yabancı Dil ile Din Kültürü ve Ahlak Bilgisi dersleri okulun kadrolu alan öğretmenlerince okutulur" (http://mevzuat.meb.gov.tr/html/ilkveokuloncyon_o/yonetmelik.pdf). Aynı madde eğer hiçbir çözüm bulunamazsa sınıf öğretmeninin İngilizce dersine girebileceğini söylüyor. Dolayısıyla, MEB bu derse özellikle İngilizce öğretmenlerinin girmesini istiyor. Son yıllarda atanan öğretmen sayısı dikkate alındığında bugün ülkemizin çoğu yerinde İngilizce öğretmeni bulamama gibi bir sorunla karşılaşılmıyor; ancak ders yüklerinin fazla olması durumunda bu derslere bazı okullarda sınıf öğretmenlerinin girdiğini söyleyebiliriz.

Nicelik olarak şu anda çok sorun yaşanmayan İngilizce öğretmenleriyle ilgili nitelik tartışmaları hep olmuştur. Anadil konuşuru öğretmenlere göre avantajları ve dezavantajları olan yerli öğretmenler avantajlarını en üst düzeyde kullanabilirlerse aslında İngilizce öğretimiyle ilgili çoğu sorun aşılacaktır. Bunun için de nitelikli öğretmen ve öğretmen adaylarına ihtiyacımız vardır. İngilizce öğretmeni yetiştiren lisans programlarına göz attığımızda başta İngilizce Öğretmenliği olmak üzere, İngilizce Mütercim-Tercümanlık, Çeviribilim, İngiliz Dili ve Edebiyatı, İngiliz Dilbilimi ve Amerikan Kültürü ve Edebiyatı programları karşımıza çıkmaktadır. İngilizce Öğretmenliği hariç diğer programların mezunları ancak pedagojik formasyon eğitimi almaları koşuluyla İngilizce öğretmeni olarak atanabilmektedir. Bu listede Anadolu Üniversitesi bünyesinde bir süre aktif olan, 2 yll örgün 2 yl uzaktan eğitim veren Açıköğretim İngilizce Öğretmenliği Programı da bulunmaktaydı (Seferoğlu, 2004). Ancak kısmi de olsa açık öğretimle öğretmen yetiştirilemeyeceğine dair tartışmalar üzerine ilgili program 2012-2013 öğretim ylı itibariyle öğrenci alımını durdurmuştur (http://abp.anadolu.edu.tr/tr/program/programProfili/1651/8). Mevcut duruma baktığımızda, söz konusu altı farklı programın da mezunlarının İngilizce öğretmeni olabildiği görülmektedir Bu çeşitlilik özellikle pedagojik formasyon eğitimi bağlamında tartışmalara yol açmaktadır (Seferoğlu, 2004; Altan, 2012). Eğitim Fakültesi çıkışlı olmayan mezunların bazen hızlandırılmış programla, bazen kısmi uzaktan eğitim programlarıyla formasyon alıp öğretmen olmaları nitelik noktasında daha fazla soru işaretine sebep olmaktadır. Türkiye'deki İngilizce eğitiminin sorunlarını konuşmaya mevcut öğretmenlerin profillerini değerlendirerek başlamak gerektiğini vurgulayan Cephe (2014) şu sorulara cevap bulmamız gerektiğini ifade ediyor:

Milli Eğitim Bakanlığı tarafından istihdam edilen öğretmenlerin yüzde kaçı İngilizce Öğretmenliği mezunudur ve bu öğretmenlerin İngilizce Öğretmenliği mezunu olmayan İngilizce öğretmenlerine oranı nedir?

İngilizce öğretmeni olarak istihdam edilenlerin mezuniyet alanları nedir ve bunun yanı sıra dil ve alan yeterlikleri ne seviyededir? (s. 62-63). 
Bu sorulara net rakamlarla cevap vermek çok güç. Gerçi İngilizce Öğretmenliği programlarında da her şeyin yolunda gittiğini söylemek yanlış olur. Özellikle ülke genelinde artan üniversite ve program sayısıyla birlikte bu programa gelen öğrencilerin hazır bulunuşluk düzeylerinde gözle görülür bir azalma yaşandı. Bazı öğrencilerin daha kendi İngilizce donanımlarını yeterli seviyeye getiremeden mezun olup atandıkları yadsınamaz bir durumdur. Bunun için ilgili programlarda öğretim elemanlarının işi sıkı tutup gerekli liyakati sağlayamayan öğrencileri mezun olma aşamasına getirmemeleri elzemdir. Yoksa liyakatsiz İngilizce öğretmenleri atandıkça yabancı dil eğitimi tartışması Türkiye'de kaçınılmaz olarak bir kısır döngüye girer. Bu çerçevede, Tatar (2010) lisans eğitiminde kapsanması gereken alanları şu şekilde siralıyor:

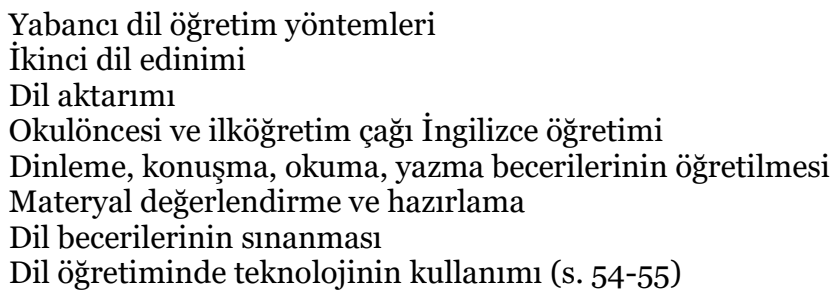

Yukarıdaki listede görüldüğü gibi İngilizce öğretmeni adaylarının çok geniş bir yelpazede donanımlı olarak yetişmesi beklenmektedir. Bu çerçevede, gerek İngilizce Öğretmenliği programları gerekse diğer bahsi geçen programların mezunlarına formasyon eğitimi veren birimler bu alanlarda asgariyi sağlayamayan öğrencileri istenilen seviyeye getirmeden mezun etmemeliler. ÖSYM tarafından atama öncesi aday İngilizce öğretmenlerine uygulanan Öğretmenlik Alan Bilgisi Testi’ne (ÖABT) ait 2017 verileri 11.535 İngilizce öğretmeni adayının bu sınava girdiğini ve ortalama doğru cevap sayısının 50 soru üzerinden $24.439 \quad$ olduğunu göstermektedir (https://dokuman.osym.gov.tr/pdfdokuman/2017/KPSS/OABT/Sayisal Bilgiler 04082017.pdf). Bu ortalama diğer bazı branşlarla kıyaslandığında (örn. İlköğretim Matematik: 16.925, Lise Matematik: 11.877, Kimya: 14.091) yeterli gibi görünebilir; ancak ortalama doğru cevap oranı açıkça yarının altındadır. Bu sonuçları bir de bu sınavda adaylara yöneltilen soruların çoktan seçmeli sorular olduğu gerçeği bağlamında değerlendirdiğimizde durumun vahameti daha iyi anlaşılmaktadır.

Öğretmen eğitimiyle ilgili diğer bir önemli husus ise Okul Deneyimi ve Öğretmenlik Uygulaması derslerinin işlevi ve verimi konusudur. Bu dersler yıllardır birçok öğrenci ve öğretim elemanı tarafından formalite olarak değerlendirildi ve ciddiye alınmadı. Halbuki sınıfta yapay ortamda uygulaması yapılan becerileri gerçek ortamda gözlemleyip uygulamaya koymak hizmet öncesi süreçte öğretmen adayları için çok değerli bir firsattır. Bu noktadaki sorunu tespit eden MEB son iki yıldır staj okullarını kendisi belirlemekte ve MEBBİS üzerinden uygulama öğretmeni ve ders sorumlusu öğretim elemanı tarafından birlikte verilen staj notunu artık öğretmen atamalarında kullanmaktadır.

Özetle, ne kadar iyi tasarlanmış bir öğretim programınız ve ders kitabınız olursa olsun, onları sınıfta uygulamaya dökecek öğretmeniniz programın ondan istediği şekilde hareket etmiyorsa sisteminiz işlemiyor demektir. Çünkü dil eğitimi insanla ve diyalogla yapılacak bir iş ve bu süreci sınıfta yönetecek kişi de öğretmenler. Yalçın (2017) bu çerçevede 'Yabancı Dil Öğretimi İçin Önce Öğretmen' (s. 1) sloganıyla öğretmen faktörünün önemine işaret etmektedir. MEB hem Diller İçin Avrupa Ortak Başvuru Metni (CEFR) hem de güncellenen öğretim programlarıyla ilgili hizmet içi eğitimler vermekte; fakat bazı öğretmenlerin konformist davranıp eski alışkanlıklarla geleneksel dil öğretim yöntemlerine yönelmeleri halen gramer ağırlıklı bir sistemin var olduğu gibi bir yanlış algı oluşmasına sebep olabilmektedir. 


\section{Zaman Gerektiren Bir Süreç}

Türkiye’de İngilizce öğrenmeyi güç kılan diğer bir boyut ise bu konuda aceleci davranılmasıdır. Dil öğrenmek emek ve sabır gerektiren bir süreçtir. İngilizceyi Türkiye'de öğrenmek Kanada'da öğrenmekten farklı olacaktır. Çocuk anadilini edinirken bile yaklaşı 2-2.5 yllık bir alımlama (reception) dönemi geçirir ve sonrasında dili üretmeye başlar. Anadilini tam olarak konuşabilmesi içinse en az 5-6 yaşına gelmesi gerekir. Dolayısıyla 3 ay İngilizce dersi aldıktan sonra 'Hadi bakalım İngilizce konuş da dinleyelim' talebine maruz kalmak öğrenenin cesaretini kırmamalıdır. Doğru bir dil öğrenme süreci sabırla yürütüldüğünde muhakkak meyvelerini verir.

Planlama olarak baktığımızda ise eğitim de dil öğretimi de çok uzun süreli bir yatırımdır. Örneğin, 2013 ve 2018 müfredat değişiklikleri ülkemizde İngilizce öğrenimi ve öğretiminde çığır açmayı planlayan adımların neticesidir. Bu programların meyvelerini 5-10 yll sonra daha net görmeye başlayacağız. Öğretmenlerin yeni sisteme alışması, öğrenci ve veli alışkanlıklarının kırılması ve sistemin sürdürülebilirliğinin yerleşmesi için biraz sabır ve zamana ihtiyaç vardır.

\section{Mevcut Önyargilar}

Ülkemizde uzun yıllar başarısızlıkla sonuçlanmış dil öğretim süreçleri insanlarda Türkiye'de bu işin olamayacağına dair bir önyargı oluşturdu. Hatta işi daha ileriyi taşıyıp millet olarak genetik yapımızın dil öğrenmeye elverişli olmadığını iddia edenler bile bulunmaktadır. Ancak durum çok daha farklı bir boyuttadır. İngilizce öğrenme noktasında sorun yaşayan tek ülke biz değiliz. Genişleyen çemberde bulunan ülkelerin çoğunda benzer problemler yaşanıyor. Bu farkındalıkla özellikle nitelikli İngilizce öğretmeni yetiştirme sorunumuzu aşabilirsek mevcut öğretim programlarılya birlikte çoğu şeyin iyi yönde değişmemesi için hiçbir neden yok. Aslında toplumda İngilizcenin Türkçe dâhil pek çok dile nazaran öğrenmesi daha kolay bir dil olduğuna ilişkin bir farkındalığın gelişmesini sağlamak zorundayız. Bunun için de erken yaşta etkin yaklaşımlarla dil öğrenmeye başlamış bir nesle ihtiyacımız var. Bu yönde adımlar da daha 4-5 yıl öncesinde atıldığı için bu önyargının tam olarak kırılmasına toplum olarak biraz daha zamanımız bulunmaktadır. Ancak olumlu yönde atılan adımlar Firsatlar başlığı altında ayrıntılı olarak ele alınacaktır.

\section{Yerli Kitapların İstenilen Seviyeye Gelememesi}

MEB son yllarda devlet okullarında İngilizce dâhil olmak üzere bütün ders kitaplarını ücretsiz olarak öğrencilere dağıtıyor. Bu aslında getireceği bilgi ve deneyim birikimi açısından çok büyük bir adım. Bu işte en kilit rolü Talim ve Terbiye Kurulu Başkanlığı oynuyor. Öğretim programlarının hazırlanmasından da sorumlu olan bu birim güncel programlar çerçevesinde kendilerine yapılan taslak kitap başvurularını geliştirdikleri panel sistemiyle hem akademiden doktoralı uzmanlar hem de işin uygulayıcısı konumundaki İngilizce öğretmenleri ile görsel tasarım uzmanlarından oluşan ekiplerin çalışmasıyla değerlendirip karara bağlamaktadır.

Talim ve Terbiye Kurulu tarafından uygulanan bu sistem Türkiye'de diğer ders kitaplarının yanında İngilizce kitaplarının da yerli olarak üretimi ve basımı noktasında büyük bir önem arz etmektedir. Ancak, bir İngilizce kitabı hazırlamak bir Coğrafya kitabı hazırlamaktan çok daha farklıdır. Bu çerçevede, hazırlanan kitaplar her ne kadar öğretim programlarıyla uyumlu olsa da içerik, organizasyon ve görsel unsurlar bakımından eksiklikleri bulunmaktadır. Bu da okullardaki öğretmenlerde bir güven problemi oluşturup onları yabancı yayınevleri tarafından basılan kitapları kullanmaya sevk etmektedir. 
MEB şu anda Talim ve Terbiye Kurulu'nun onayını almamış hiçbir kitabı devlet okullarında kullanmaya müsaade etmiyor; ancak özellikle özel okullarda sistem büyük ölçüde Oxford, Longman, Cambridge, Macmillan gibi yayınevlerinin kitaplarıyla yürüyor. Bu da devlet okulları ve özel okullar arasında İngilizce eğitimi adına ciddi bir materyal farkı doğurmaktadır.

Tüm bu gelişmeleri değerlendirdiğimizde, MEB’in yerli İngilizce ders kitabı çalışmaları çok önemli ve cesur adımlar olarak görülmelidir. Ancak, eksikliklerin giderilmesi ve oluşan güven probleminin ortadan kaldırılabilmesi için bu kitapların yazımı aşamasında yukarıda bahsedilen ve bu alanda asırlık tecrübesi olan yayınevleriyle işbirliği yapılabilir. Yürütülecek bu ortak kitap projeleriyle, anadil konuşuru tecrübeli yazarların katkıları alınıp Türkiye’ye özgü İngilizce ders kitapları hazırlanabilir. İşbirliği noktasında atılacak isabetli adımlarla birlikte ders kitabı sorunu ortadan kalkabilir.

\section{Ölçme-Değerlendirme Araçlarının Etkin Kullanılamaması}

Gerek okullarda dönem boyunca girilen sınavlar gerekse büyük ölçekli sınavlar (high-stakes examinations) öğrenme süreci üstünde oldukça etkilidir. Sinav etkisi (washback effect) olarak adlandırdı ̆̆ımız bu boyut dil öğrenenleri olumlu veya olumsuz bir şekilde yönlendirebilmektedir. Sinavları öğrencilere not verme veya onları cezalandırma aracı olarak görmemek gerekiyor. Aksine onları öğrenme firsatı olarak öğrencilerin önüne sunmak dil öğrenme sürecinin lehine olacaktır. Sınav etkisi bağlamında zaman zaman yapılan bir öğretmen hatası da sınav kâğıtlarının öğrencilere sınavdan makul bir zaman sonra gösterilmemesidir. Bazı öğretmenler kâğıtları öğrencilere hiç göstermemeyi tercih ederken bazıları da sınav kâğıtlarını çok geç değerlendirip sınava ilişkin hatırlanan bilgilerin ciddi oranda azalmasına sebep olmaktadır. Bu iki uygulama da sınav etkisi bağlamında İngilizce öğrenmeyi olumsuz etkilemektedir.

Sınavların içeriğine değinecek olursak okul sınavlarını ve büyük ölçekli sınavları ayrı değerlendirmekte fayda var. İlkokul, ortaokul ve ortaöğretim düzeyleri için hazırlanmış güncel İngilizce dersi öğretim programları ölçme-değerlendirme bağlamında uygulanacak sınavların dört temel beceriyi kapsaması ve dil unsurlarını örtük bir şekilde ölçmesi gerektiğini söylüyor (MEB, 2018). Derste öğretim programının öngördüğü şekilde tüm becerileri içine alan bir yaklaşım sergileyip sınavda dinleme ve konuşma becerilerini ölçmemek öğrenciye bu becerilerin önemi hakkında çok yanlış bir mesaj verecektir. Dolayısıyla sınav hazırlama ve kâğıtları değerlendirme işi titizlikle yürütülmeli ve tüm ölçmedeğerlendirme süreci öğrenen ve öğrenme lehine dönüştürülmelidir.

Büyük ölçekli sınavlar bağlamında ise, Türkiye'de yıllardır uygulanan İngilizce sınavlarına göz atmak yerinde olacaktır. Kamu Personeli Yabancı Dil Bilgisi Seviye Tespit Sınavı (KPDS) ve Üniversitelerarası Kurul Yabancı Dil Sınavı (ÜDS) ülkemizde yıllarca ÖSYM tarafından uygulanmış sınavlardı. 2013 yllı itibariyle bu iki sınav Yabancı Dil Bilgisi Seviye Tespit Sınavı (YDS) çatısı altında birleştirildi. Almanca, Arapça, Fransızca, İngilizce ve Rusça dillerinde yapılan bu sınavda adaylara çoktan seçmeli 80 soru yöneltiliyor. Sorular dilbilgisi, kelime bilgisi, cümle tamamlama, okuduğunu anlama, çeviri ve diyalog tamamlama gibi türlerden oluşmakta ve çoktan seçmeli bir yapıda sunulmaktadır. Türkiye'de insanların lisansüstü eğitime giriş, akademik kadrolara başvuru, yabancı dil tazminatı alma gibi geniş bir amaç yelpazesi için girmek zorunda olduğu bu sınav sadece alımlayıcı becerilerden (receptive skills) okuduğunu anlama ve alt dil becerilerinden dilbilgisi ve sözcük bilgisi gibi çok sınırlı bir alanı ölçmektedir. Dört ana dil becerisinden üçünü teşkil eden dinleme, konuşma ve yazma becerileri bu sınavda ölçülmemektedir. Benzer şekilde, 2017'de YÖK tarafından YDS’nin zor olduğuna dair şikâyetler üzerine başlatılan YÖKDİL sınavı da İngilizce, Fransızca, Arapça ve Almanca dillerinde yılda iki kez 
uygulanmakta ve katılımcılara YDS ile benzer formatta biraz daha basit sorular yöneltmektedir. Ayrıca, İngilizce öğretmeni olarak atanabilmek için gerekli KPSS sınavı ve o kapsamda yapılan İngilizce alan sınavı (ÖABT) da çoktan seçmeli formatta yapılmaktadır. Çoktan seçmeli dil sınavlarıyla ilgili tek teknik değişikliği ÖSYM tarafından üniversite giriş sınavları kapsamında uygulanan yabancı dil sınavlarına 2017'den itibaren birkaç açık uçlu soru eklenmesiyle gerçekleşti. Ancak, küçük çaplı da olsa güzel bir adım olan bu değişiklik de dil becerilerinin çoğunun ölçülmediği gerçeğini değiştirmedi. İngilizce öğrenme süreci açısından değerlendirdiğimizde, TOEFL veya IELTS gibi çoklu dil becerilerini ölçen uluslararası sınavları tercih etmeyenler Türkiye'de uygulanan bu tür dil sinavlarında başarılı olmak üzere dil öğrenim süreçlerini şekillendirirlerse, ki bunu yapan milyonlarca insan var, bu süreç onlar için YDS'den 90 puan alıp İngilizce konuşamayanlar arasına katılmakla sonuçlanabilir. Bu bağlamda sınav etkisi boyutu ciddiye alınmalı ve ÖSYM ve YÖK tarafından yapılan dil sınavlarında muhakkak üretici beceriler (productive skills) başta olmak üzere farklı beceriler de ölçülmelidir.

Ölçme-değerlendirme bağlamında yukarıda bahsedilen hususlara ek olarak, MEB'in ilkokul, ortaokul ve lise seviyesinde uyguladığı sınıf geçme yönetmeliği de öğrenme sürecine olumsuz etki edebilmektedir. Öğrencide oluşabilecek 'nasıl olsa geçerim' algısı dil öğrenme sürecine odaklanma ve süreci sahiplenme noktasında ciddi dezavantajlar doğurabilmektedir. Benzer şekilde, liselerde öğrencilerin özellikle 10. sınıftan itibaren üniversite giriş sınavı hazırlı̆̆ına girişmeleri de okulda aldıkları İngilizce dersleri ve bağımsız yürütebilecekleri okul dışı dil becerisi geliştirme süreçlerine olumsuz etki edebilmektedir.

\section{Firsatlar}

\section{Güncel Öğretim Programları}

Türkiye'de yıllar boyu dil becerileri doğanın kanununa ve işleyişine aykırı bir sırayla öğretildi. Bir bebek daha anne karnındayken dinleme yapmaya başlar ve bu süreç yaklaşı 2 yaşına kadar devam eder. Hemen sonrasında konuşma becerisi adım adım gelişir ve okuma-yazma becerileri ilkokul aşamasında gelişmeye başlar. Ancak biz yıllarca dilbilgisi ağırlıklı dil öğretim süreçleriyle doğanın bu dinlemekonuşma-okuma-yazma sırasını ihlâl ettik. Ancak, 2013 müfredat değişikliği ve 2018 güncellemesiyle birlikte doğanın koymuş olduğu kanuna geri dönüldü ve 2. sınıftan itibaren dinleme ve konuşma temelli bir İngilizce eğitimine geçildi. Bu yeni sistemle, öğrenci İngilizce okuma ve yazmayla 4. sınıfta kısmi olarak tanışıp 8. sınıf bitene kadar dinleme ve konuşma becerileri öncelenmiş bir dil eğitimi almaktadır. Lise aşamasında da aynı yaklaşımla şekillenmiş İngilizce eğitimi devam etmektedir. Bu köklü değişiklerle birlikte İngilizce öğrenme süreci çok daha etkin ve verimli bir boyuta ulaşmıştır ve sistem yerleştikçe alınan verim çok daha iyi seviyelere gelecektir.

Yeni öğretim programıla gelen bir diğer köklü değişiklik ise İngilizce eğitiminin 2. sınıftan itibaren başlatılmasıdır. Lenneberg (1967) ve sonrasında Krashen'ın (1982) ortaya koyduğu Edinim Eşiği (Critical Age) Hipotezi'nin ortaya koyduğu erken yaş ilkesini dikkate alan bu yaklaşım öğrencilerin dil öğrenmek için geç kalmamasını sağlamayı amaçlıyor. Bu erken yaş uygulaması yukarıda bahsedilen doğru beceri sıralamasıyla birleşince öğrenciler için doğru bir dil öğrenme sürecinin başlamasını sağllyor.

Yeni öğretim programının temel ilkelerinden birisi de Diller İçin Avrupa Ortak Başvuru Metni’nin ortaya koyduğu eylem odaklı öğrenme anlayışıyla dili öğretmeyi amaçlamasıdır. Öğrenen ve öğrenme sürecini öne alan bu anlayış öğrencilerin İngilizceyi kullanarak ve yaşayarak öğrenmeleri noktasında uygun bir zemin oluşturmayı amaçlamakta ve Yapılandırmacı Yaklaşım çerçevesinde öğrenen özerkliğini 
desteklemektedir. Bu sayede öğrenmeyi öğrenen öğrenciler İngilizce öğretmenlerinin yanlarında olmadığı zamanlarda da İngilizcelerini geliştirebilme becerisi kazanmaktadırlar.

Son güncellemeyle birlikte ise, adalet, dostluk, dürüstlük, öz denetim, sabır, saygı, sevgi, sorumluluk, vatanseverlik ve yardımseverlik (friendship, justice, honesty, self-control, patience, respect, love, responsibility, patriotism and altruism) gibi değerleri örtük bir şekilde İngilizce ders kitaplarında göreceğiz. Bu da öğrencilerimizin kendi kimliklerini tanıma ve koruma farkındalığıyla İngilizce öğrenme süreçlerini yürütecekleri ve bu süreci kültürel ve ahlâki anlamda ekstra bir kazanca dönüştürebilecekleri anlamina gelmektedir.

Fırsat olarak değerlendirebileceğimiz bir başka husus ise bu yıl pilot uygulaması yapılan İngilizce ağırlıklı 5. sınıf çalışmasıdır. Bu uygulama 4+4+4 sisteminde birinci kademeyi bitiren öğrencilerin erken yaşta aldıkları İngilizce altyapısını yaşları çok geçmeden ikinci kademenin ilk yılında iyice pekiştirmelerini amaçlamaktadır. Pilot uygulamalardan gelecek olumlu dönütlerle bu uygulamanın ülke geneline yayılması planlanmaktadır. Aslında, eğitim sistemimiz daha önce böyle bir deneyim yaşadı. 1997-1998 eğitim-öğretim yllında zorunlu eğitimin 8 ylla çlkarılmasından önce Anadolu Liseleri başlangıçta bir yıl İngilizce hazırlık içeren ve ortaokul ve lise kısmını tek çatı altında birleştiren bir sisteme sahipti (Çetintaş ve Genç, 2001). Demirel (1999) bu uygulamayı şu şekilde özetlemektedir:

1992-1993 öğretim yılından geçerli olmak üzere lise önüne bir yll yabancı dil hazırlık sınıfının konulması ile yabancı dil ağırlıklı program uygulamasına 28 okulda başlanmıştır. Bu uygulama ülke genelinde yaygınlaştırılmış ve 1997-1998 öğretim yılında yabancı dil ağırlıklı okul sayısı 662’ye ulaşmıştır. Bu okulların beşinde Almanca, on ikisinde hem Almanca hem İngilizce, birinde de Almanca, Fransızca, İngilizce hazırlık sınıfları mevcuttur. Diğer 644 okulda ise yalnız İngilizce hazırlık sınıfları bulunmaktadır (s. 27).

İngilizce eğitimi adına olumlu bir deneyim olan bu uygulama 8 yıllık kesintisiz eğitimle birlikte hazırlık sınıfının lisenin başlangıç yılına çekilmesiyle ortadan kalkmış ve erken yaş avantajı da kaçırılmıştır. Bugün planlaması yapılan 5. sınıflar için yoğun İngilizce programı eski Anadolu Lisesi sisteminin esintilerini taşımaktadır.

\section{Teknolojik Gelişmeler}

21. yüzyll teknoloji ve bilgi çağı olma özelliğiyle bütün ezberleri bozmuş ve tüm alanlarda olduğu gibi eğitimde de çı̆̆ır açıcı yeniliklere vesile olmuştur. Dil eğitimi bağlamında ise Teknoloji Destekli Yabancı Dil Öğrenimi (Technology-Enhanced Language Learning- TELL), Bilgisayar Destekli Yabancı Dil Öğrenimi (Computer-Assisted Language Learning- CALL) ve Mobil Cihaz Destekli Yabancı Dil Öğrenimi (Mobile-Assisted Language Learning- MALL) gibi akımlar dil öğrenme sürecine, özellikle de öğrenen özerkliğini artırarak, büyük katkı sağlamıştır. Yararlanabileceğimiz binlerce faydalı yazılım, e-kitap, internet sayfası ve akıllı telefon uygulamaları da İngilizce öğrenmek isteyenlerin hizmetindedir.

Teknolojik gelişmeler zorluklar kısmında değindiğimiz yabancı dil ortamı kısıtllılı̆ını ve İngilizceyi pratik yapma eksikliğini de kısmen ortadan kaldırabiliyor. Örneğin, Skype ve Google Hangouts gibi yazılımlar sayesinde Türkiye'de İngilizce öğrenenler rahatlıkla yurtdışında yaşayan bir anadil konuşuruyla sesli ve görüntülü olarak iletişime geçebiliyor. Yine Voki ve GoAnimate gibi pek çok yazılım sayesinde İngilizce konuşma becerileri eğlenceli bir şekilde geliştirilebiliyor. İnternet sayesinde sayısız özgün materyale erişim de artık mümkün olabilmektedir. 
Teknolojik gelişmelerden faydalanmak adına 2010 yılında MEB tarafından başlatılan FATïH (Fırsatları Artırma ve Teknolojiyi İyileştirme Hareketi) Projesi kapsamında ülke genelinde devlet okullarının hemen hepsinde sinıflara akıllı tahta kuruldu ve öğrencilere tablet dağıtıldı. Dağıtılan tabletlerle ilgili amaçlanan verim tam alınamasa da akıllı tahtalar çok etkin bir şekilde İngilizce dâhil hemen her derste kullanılmaktadır. Teknoloji çağının içine doğan ve dijital yerli veya z kuşağı olarak tanımladığımız yeni nesil için bu tür teknolojik destekler yerinde ve etkin kullanılırsa öğrenmeyi artırıcı etki yapabilir. Bugün devlet okullarının sahip olduğu bu imkâna ülkemizde bulunan pek çok üniversite bile sahip değil.

\section{Kaynak Çeşitliliği}

Geçen zaman ve edinilen birikimler İngilizce eğitimi bağlamında hem elektronik hem de basılı olarak sayısız kaynağın üretilmesini sağlamıştır. Sözlüklerin, kitapların, dergilerin, İngilizce görsel ve işitsel yayınların çeşitliliği bugün Türkiye'de İngilizce öğrenenler için bulunmaz fırsatlar sunmaktadır. Ulaşılamayan kaynak yok denecek kadar azdır. En güncel kaynaklardan 50-60 yll öncesinin kaynaklarına varana kadar her şey bugün erişilebilir durumdadır. Sahaflar bile artık internet üstünden satış yapmakta ve İngilizce öğrenenler için büyük bir derya sunmaktadır. Türkiye’de bulamadığınız bir kaynağı bile en geç bir ay içinde uluslararası kitap satış sitelerinden getirtebiliyorsunuz. Ayrıca, kütüphanelerin erişime sunduğu basılı ve elektronik kitap sayıları eskiye nazaran çok daha iyi durumdadır. Görsel ve işitsel kaynaklara bakıldığında ise bugün Türkiye'de İngilizce yayın yapan birkaç farklı gazete ve televizyon kuruluşu mevcuttur. İnternet veya uydu kanalıyla ulaşlabilecek görsel ve işitsel kaynakların ise sınırsız olduğunu söyleyebiliriz.

\section{Etraftaki İngilizce}

Bir yerdeki sokak tabelaları, mağaza isimleri, trafik uyarıları gibi görsellerde bulunan dil çeşitliliğini ifade eden dilsel durum (linguistic landscape) bugün dünyada çoğu yerde İngilizcenin lehine yerel dillerin ise aleyhine durumdadır. Ülkemiz de bu bağlamda bir istisna değildir. Sokağa çıktı̆̆ımızda özellikle mağaza isimlerinin pek çoğunda İngilizce etkisi görmekteyiz. Bu durum Türkçenin korunması açısından arzu ettiğimiz bir durum olmamakla birlikte İngilizcenin öğrenilmesi noktasında bazı yararlar getirebilir. Gözlemlenen farklı kelimeler bir merak duygusu uyandırıp özellikle sözcük bilgisi bağlamında öğrenme sürecine bir ivme kazandırabilir. İngilizceyi bugün sadece mağaza isimlerinde değil aynı zamanda kullandığımız hemen her üründe de görebiliyoruz. Kolumuzdaki saatin içindeki 'water resistant', içtiğimiz sütün kutusundaki 'UHT', belimizdeki kemerin iç kısmındaki 'genuine leather', satın aldığımız içeceğin üstündeki 'sugar-free', bilgisayarımızın klavyesindeki 'delete, print screen, caps lock', televizyonumuzun kumandasındaki 'on/off, mute' gibi binlerce İngilizce ifadeyi her gün görüyoruz aslında. Bu tür unsurları öğrenme sürecinin içine katarak İngilizceyi hem gerçek yaşamla ilintili hale getirmiş oluruz hem de merak ve öğrenme duygumuz sürekli canlı kalır.

\section{Projeler}

Küreselleşen dünya şartlarında insanların hareketliliği ve girişkenliği de artmaktadır. Bu bağlamda ulusal ve uluslararası düzeyde projeler İngilizce öğrenme noktasında da firsatlar sunmaktadır. Türkiye'de Ulusal Ajans koordinatörlügünde Erasmus+ projeleri gerçekleşmekte ve bu projeler kapsamında öğrenci ve öğretmen/öğretim elemanı değişimleri yapılmaktadır. YÖK bünyesinde yürütülen Mevlana Programı çerçevesinde de üniversite öğrencileri ikili anlaşmalarla farklı ülkelere gitme olanağı bulmaktadır. 


\section{Sonuç ve Değerlendirme}

Ülkemizde İngilizce eğitiminin niteliği hep tartışlagelen bir konu olmuştur. Aslında, uygulanan sistemleri değerlendirdiğimizde uzun yıllar istikrarlı bir şekilde yürürlükte kalan ve başarılı olan bir dil eğitimi sisteminden de bahsedemeyiz. İngilizcenin yabancı dil olarak öğrenildiği ve kullanıldığı bir ülke olan Türkiye'de doğal ortamında geliştirilme olanağı kısıtlı olan İngilizce becerileri sık sık değişen sistemler nedeniyle arzu edilen seviyeye getirilememiştir. Ancak son ylllarda İngilizce eğitimi adına isabetli bazı adımların atıldığını söyleyebiliriz.

Gelmiş olduğumuz aşama göz önüne alındığında Türkiye'de İngilizce öğrenmeyi güç kılan bazı etkenlerin ısrarlı varlığını yadsıyamayız. Ancak, eskiden bahsedilen Türkiye'de düzgün bir yabancı dil öğretim planlamasının olmaması (Işık, 2008), bu işin uygulayıcısı olan İngilizce öğretmenlerinin fikirlerinin öğretim programı ve ders kitaplarının hazırlanması aşamasında alınmaması ve bunun sonucunda oluşan müfredat sorunları (Tütüniş, 2014), öğretmen sayılarının oldukça sınırlı olması (Kırkgöz, 2005), öğretim teknolojilerinin öğretmenler tarafından yeterince tanınmaması gibi etkenlerin bugün büyük oranda ortadan kalktığını görmekteyiz. Ancak, İngilizcenin Türkiye'de ikinci dil değil yabancı bir dil olarak öğrenilip kullanılmasının getirdiği doğal ortamda öğrenememe kısıtlllı̆̆ı, öğretmen nitelikleri bağlamında özellikle hizmet öncesi aşamada yaşanan bazı sorunlar ve bunların atanan İngilizce öğretmenlerinin yeterlikleri açısından oluşturduğu dezavantajlar, atanmış İngilizce öğretmenlerinin yöntemsel açıdan eski alışkanlıklarını kırma konusundaki isteksizlikleri, dil becerisi geliştirmenin zaman ve sabır gerektiren bir süreç olması, İngilizce öğrenenler arasında hâlâ dil öğrenme sürecine dair mevcut önyargılar, yerli kitapların tam olarak istenilen seviyeye gelememesi ve ölçmedeğerlendirme araçlarının hem okul içi sınavlar hem de büyük ölçekli sınavlar düzeyinde etkin kullanılamaması gibi sorunlar bugün hâlâ İngilizcenin Türkiye'de öğrenilmesini güç kılan ve çalışmanın başında paylaşılan Türkiye adına 2011-2017 arası İngilizce Yeterlik Endeksi sonuçlarının ortaya çımasında büyük payı olan etkenler arasındadır.

Mevcut duruma iyi tarafından baktığımızda ise iyi hazırlanmış güncel öğretim programlarının yürürlükte olması, eğitim sistemi açısından İngilizce eğitiminin 2. sınıftan itibaren başlatılması, dil öğrenme sürecini destekleyen teknolojik gelişmeler, sınırsız sayıda kaynağa erişim olanağı, artık her yerde bulunan İngilizce unsurları dil öğrenme sürecine katma olanağı ve Erasmus+ gibi uluslararası projeler kapsamında yurtdışındaki okullara gitme olanaklarının artması gibi Türkiye'de İngilizce öğrenme sürecini kolaylaştıracak etkenlerden de bahsedebiliriz.

Dil öğrenme uğraşı herhangi bir hapı veya iksiri bulunmayan uzun soluklu bir süreçtir. Türkiye özelinde bu süreci, avantaj ve dezavantaj doğuran etkenleri iyi tespit edip dil eğitiminde güncel eğilimler çerçevesinde bütüncül bir yaklaşımla öğrenen ve öğrenme odaklı bir düzlemde yürütmeliyiz. Yaşanan sorunlar karşısında atılan çözüm adımlarının sonuçlarını da sabırla bekleyip öyle değerlendirmemiz gerekir.

\section{Kaynakça}

Altan, M. Z. (2012). Redesign of the Teacher Education System: A Turkish Case. Paper presented at the 4th ATEE Winter Conference:Teacher Educators policy, practice and research, 225-231.

Bayyurt, Y. (2014). 4+ 4+ 4 Ĕ̆itim Sisteminde Erken Yaşta Yabancı Dil Ĕ̆itimi. Yabancı Dil Eğitimi Çalıştayı Bildirileri (12-13 Kasım 2012), Ankara: Hacettepe Üniversitesi Yayınları, s. 117-127.

British Council ve TEPAV (2013). Türkiye'deki Devlet Okullarında İngilizce Dilinin Öğretimine İlişkin Ulusal İhtiyaç Analizi. Ankara: Yorum Yayın. 
Türkiye’de İngilizce Öğrenmek: Zorluklar ve Fırsatlar / İ. Yaman (p. 161-175)

British Council ve TEPAV (2015). Türkiye'de Yükseköğretim Kurumlarında İngilizce - Bir Durum Analizi. Ankara: Yorum Yayın.

Cephe, P. T. (2014). İngilizce Öğretmeni Eğitiminde Yaklaşımlar ve Uygulamalar. II. Ulusal Yabancı Dil Eğitimi Çalıştayı Bildirileri (8-9 Kasım 2013), Samsun: Hedef Kopyalama, s. 59-64.

Çakır, A. (2017). Türkiye'de YÖK Öncesi ve Sonrası Yabancı Dil Eğitimi. Journal of Language Research (JLR), 1(1), 1-18.

Çetintaş, B. \& Genç, A. (2001). Eğitim Reformu Sonrası Anadolu Liselerinde Yabancı Dil Öğretimi. Hacettepe üniversitesi Eğitim Fakültesi Dergisi, 20, 51-56.

Demirel, Ö. (1999). İlköğretim Okullarında Yabancı Dil Öğretimi. Ankara: Milli Eğitim Basımevi.

Demirpolat, B. C. (2015). Türkiye’nin Yabancı Dil Öğretimiyle İmtihanı: Sorunlar ve Çözüm Önerileri. SETA. http://file.setav.org/Files/Pdf/20150707131308_131_yabancidil_web.pdf Erişim Tarihi: 27.03.2018.

Doğançay-Aktuna, S. (1998) The Spread Of English in Turkey And Its Current Sociolinguistic Profile. Journal of Multilingual and Multicultural Development, 19(1), 24-39. Ergin, O. (1977). Türkiye Maarif Tarihi. İstanbul: Eser Matbaası.

Haznedar, B. (2004). Türkiye'de yabancı dil öğretimi: ilköğretim yabancı dil programı. Boğaziçi Üniversitesi Ĕ̆itim Dergisi, 21(2).

Haznedar, B. (2010, November). Türkiye'de yabancı dil eğitimi: Reformlar, yönelimler ve

öğretmenlerimiz. In International Conference on New Trends in Education and Their Implications, Antalya, Turkey. Erişim: http://www. iconte. org/FileUpload/ks59689/File/166. pdf .

Işık, A. (2008). Yabancı Dil Eğitimimizdeki Yanlışlar Nereden Kaynaklanıyor? Journal of Language and Linguistic Studies, 4(2), 15-26.

Kachru, B. B. (1985). Standards, codification and sociolinguistic realism: The English language in the outer circle. R. Quirk \& H. Widdowson (Haz.), English in the world: Teaching and learning the language and literatures (s. 11-36). Cambridge: Cambridge University Press.

Kırkgöz, Y. ( 2005). English language teaching in Turkey: Challenges for the 21st century. In G. Braine (Ed.), Teaching English to the world: History, curriculum, and practice (pp.159175). London: Lawrence Erlbaum Associates.

Kırkgöz, Y. (2007). English language teaching in Turkey: Policy changes and their implementations. RELC Journal, 38(2), 216-228.

Kirkpatrick, R. (ed.) (2017). English Language Education Policy in the Middle East and North Africa. Cham: Springer International Publishing.

Krashen, S. (1982). Principles and Practice in Second Language Learning and Acquisition. Oxford: Pergamon.

Lenneberg, E. (1967). Biological Foundations of Language. New York: Wiley-Blackwell.

MEB. (2018). İngilizce Dersi Öğretim Programı (İlkokul ve Ortaokul 2, 3, 4, 5, 6, 7 ve 8. Sinıflar). Ankara: Talim ve Terbiye Kurulu Başkanlığı.

MEB. (2018). Ortaöğretim İngilizce Dersi Öğretim Programı (9, 10, 11 ve 12. Sinıflar). Ankara: Talim ve Terbiye Kurulu Başkanlığı.

Medgyes, P. (1994). The Non-native Teacher. Hong Kong: MacMillan.

Seferoğlu, G. (2004). A study of alternative English teacher certification practices in Turkey. Journal of Education for Teaching, 3o(2), 151-159.

Tatar, S. (2010). İngilizcenin Yabancı Dil Olarak Öğretiminde Anadili İngilizce Olan ve Olmayan Öğretmenlerin Rolü. Boğaziçi Üniversitesi Ĕ̆itim Dergisi, 27(2).

Tütüniş, B. (2014). İngilizce Öğretiminde Yöntem Sorunları. Yabancı Dil Eğitimi Çalıştayı Bildirileri (12-13 Kasım 2012), Ankara: Hacettepe Üniversitesi Yayınları, s. 33-36. 
Yalçın, A. (2017). Yabancı Dil Öğretimi İçin Önce Öğretmen. Eğitime Bakış, 13(39), 1-2.

http://abp.anadolu.edu.tr/tr/program/programProfili/1651/8 Erişim Tarihi: 25.03.2018

https://dokuman.osym.gov.tr/pdfdokuman/2017/KPSS/OABT/SayisalBilgiler04082017.pdf Erişim Tarihi: 23.03.2018

http://mevzuat.meb.gov.tr/html/ilkveokuloncyon_o/yonetmelik.pdf Erişim Tarihi: 25.03.2018

https://www.ef.com.tr/epi/regions/europe/turkey/ Erişim Tarihi: 27.03.2018 